\title{
Heroizm miłosierdzia ks. Władysława Bukowińskiego
}

Heroizm miłosierdzia został ukazany w Ewangelii Mateusza i Łukasza oraz w Liście do Rzymian. Za podstawę do rozważań przyjmijmy Ewangelię Mateusza 5, 38-45: „Słyszeliście, że powiedziano: Oko za oko i ząb za ząb! A Ja wam powiadam: Nie stawiajcie oporu złemu. Lecz jeśli cię kto uderzy w prawy policzek, nadstaw mu i drugi! Temu, kto chce prawować się z tobą i wziąć twoją szatę, odstąp i płaszcz! Zmusza cię kto, żeby iść z nim tysiąc kroków, idź dwa tysiące! Daj temu, kto cię prosi, i nie odwracaj się od tego, kto chce pożyczyć od ciebie. Słyszeliście, że powiedziano: Będziesz miłował swego bliźniego, a nieprzyjaciela swego będziesz nienawidził. A Ja wam powiadam: Miłujcie waszych nieprzyjaciół i módlcie się za tych, którzy was prześladują; tak będziecie synami Ojca waszego, który jest w niebie; ponieważ On sprawia, że słońce Jego wschodzi nad złymi i nad dobrymi, i On zsyła deszcz na sprawiedliwych i niesprawiedliwych".

Św. Jan Chryzostom tak komentuje powyższą Ewangelię: „Widzisz, jak oraz po ilu stopniach wyprowadził was na sam szczyt cnoty. Policz je! Pierwszym stopniem jest nieczynienie zła sobie samemu. Drugi polega na niebyciu mściwym, gdy ktoś zaczął czynić nam coś złego. Trzecim jest nieczynienie temu, kto nas skrzywdził tego, czego sam doznałeś, ale zachowanie się spokojnie. Czwarty polega na ofiarowaniu samego siebie na cierpienie. Piątym jest danie nawet więcej, niż chce ten, kto żąda. Na szóstym nie ma się w nienawiści tego, który to uczynił. Siódmy polega na miłowaniu go. Ósmym jest czynienie mu dobrze. Dziewiątym zaś jest modlenie się do Boga za niego... ale najbardziej zadziwiające jest to, że stajemy się podobni Bogu, o ile ludzie mogą się w ogóle takimi stać”.

Egzegeza tekstu dokonana przez św. Jana wprowadza nas w tajemnicę życia ks. Władysława Bukowińskiego, dlatego poszczególne myśli autora chcemy przedstawić za pomocą wydarzeń z jego życia.

Ks. Bukowiński pisał: „dla mnie Chrystusowe przykazanie miłości nieprzyjaciół nie jest jakąś piękną utopią, lecz czymś w najwyższym stopniu realnym

\footnotetext{
${ }^{1}$ Św. Jan Chryzostom, Homilie na Ewangelie wg św. Mateusza, Kraków 2000, s. 232.
} 
i życiowym"2. Sługa Boży zaznacza w ten sposób, że w jego życiu spełniało się przykazanie miłości nieprzyjaciół w różnorodnych okolicznościach.

W odniesieniu do nieczynienia sobie zła ks. Bukowiński wspomina sytuację, kiedy wywożono go z Łucka do więzienia w Kijowie: tę sytuację po ludzku dramatyczną odkrywał jako nowe zadanie, które postawiła przed nim opatrzność. Żegnając z okna więziennego samochodu Łuck z jego piękną katedrą i kochanych parafian, nienawiść władz i rozpoczynające się szczególne prześladowanie składał w ręce Boga i powierzając swoją przyszłość opatrzności Bożej, był pewien, że jest to jedynie zmiana terenu jego pracy duszpasterskiej. Tak wspomina tamte chwile: „Wiedziałem, że czeka mnie tam niezmiernie wielka praca duszpasterska"3.

Wobec nieprzyjaciół, od których doznawał prześladowań, ks. Władysław nigdy nie okazywał się mściwym, nie odpowiadał złośliwością, chociaż stawał w obronie prawdy, którą głosił. Znana jest szczególna sytuacja przesłuchania ks. Bukowińskiego w 1959 roku, gdy w rozmowie z sędzią bronił motywów swojego pozostania w Kazachstanie. Oto fragment tej rozmowy: „Jasną jest rzeczą, że zostaliście w Związku Radzieckim tylko ze względów materialnych" - zwrócił się sędzia do ks. Bukowińskiego, na co on odpowiedział: „W Polsce otrzymałbym kościół parafialny ze stałym dochodem, mógłbym w nim legalnie i swobodnie pracować, a w Związku Radzieckim muszę siedzieć na ławie oskarżonych" ". Taka niemająca nic z mściwości postawa spowodowała, że agresywny sędzia już więcej się nie odezwał.

Przebywając w obozie ks. Bukowiński przeżył szczególną sytuację. Pewnej nocy, gdy po wyspowiadaniu więźnia wracał do swojego baraku, natknął się na patrol. Jeden z nich uderzył go w twarz i kazano mu wracać. Ks. Bukowiński był mocno wzburzony takim potraktowaniem: „Nie nadstawiłem, zgodnie z Ewangelią lewego policzka, tylko wróciłem do swego baraku bardzo zły i wzburzony... Niech mnie wsadzają do karceru, ale jakie on ma prawo tak mnie znieważać?" gniew i nie odpłacił złem za doznaną krzywdę. Zachował się spokojnie, przez co okazał postawę miłosierdzia wobec prześladowców.

Ofiarowanie samego siebie i skazanie się na cierpienie jest jedną z najtrudniejszych form miłosierdzia. W życiu ks. Bukowińskiego było wiele takich sytuacji, m.in. kiedy otrzymał możliwość powrotu do ojczyzny, odmówił, mając pełną świadomość dokonanego wyboru: „tym razem ja sam dobrowolnie pokierowałem swym życiem, doskonale zdając sobie sprawę z podjętej decyzji.

${ }^{2}$ W. Bukowiński, Do moich przyjaciót, Biały Dunajec-Ostróg 2001, s. 52.

${ }^{3}$ Tamże, s. 53.

${ }^{4}$ Tamże, s. 55.

5 Tamże, s. 48. 
Jedną z konsekwencji tej decyzji poniosłem trzy lata później, kiedy to 3 czerwca 1958 roku zostałem aresztowany po raz trzeci w moim życiu"'. Była to decyzja heroiczna, pociągająca za sobą inne nadzwyczajne czyny. Tej decyzji nie zmienił do końca życia mimo trudności i nalegania ze strony najbliższych.

Chrystus uczył: „Jeśli ktoś bierze ci płaszcz, nie broń mu i szaty. Daj każdemu, kto cię prosi i nie dopominaj się zwrotu od tego, który bierze twoje" (Łk 6, 29-30). Miłość nieprzyjaciół domaga się również tego, aby nawet w nadmiarze dać, czego od nas żądają. Kiedy pewnego dnia wezwano ks. Bukowińskiego na posterunek milicji, on pożegnał swoich wiernych, spakował najpotrzebniejsze rzeczy i stawił się, jak mu nakazano. Policjanci byli tak zaskoczeni i zdumieni jego gotowością na kolejne uwięzienie, że odesłali go do domu ${ }^{7}$.

Ks. Bukowiński nigdy nie odnosił się z nienawiścią do władz komunistycznych - swych prześladowców. Świadkowie znający go podkreślają, że nie narzekał i nie przeklinał tych, którzy wyrządzali mu krzywdę, chociaż miał ku temu powody, bo był ciągle nękany i doświadczył wielu niesprawiedliwości ze strony komunistycznego systemu. Traktował prześladowania jako okazję, aby utrapienia przemieniać w dobro.

Miłował wszystkich, również swoich nieprzyjaciół. Jeden ze świadków wspomina, że jako młody chłopak nie chciał się spowiadać, gdyż uważał, że to co czynił Bukowiński było głupie, a idee Lenina jedynie słuszne i godne uwagi. Dopiero po upadku systemu przy grobie niegdyś pogardzanego księdza odkrył, że był to człowiek niezwykły, który, żyjąc wiarą, uczynił ludziom wiele dobra i że to właśnie ten kapłan miał rację, że to Ewangelia jest jedynie słuszna i godna uwagi. Tak ks. Bukowiński nawet po śmierci spełnił Pawłowe polecenie: „Nie daj się zwyciężyć złu, ale zło dobrem zwyciężaj” (Rz 12, 21).

Modlitwa za nieprzyjaciół jest wyrazem naszego przebaczenia. Ona ukazuje prawdę o wnętrzu naszego serca: jak jest ono ukształtowane i jaki jest naprawdę nasz stosunek do wrogów. Miłość bowiem pragnie prawdziwego szczęścia, pragnie zbawienia człowieka. Podczas przedłużającego się śledztwa sędzia zauważył, że ks. Bukowiński modli się i zapytał: „A co wy tam robicie?”. Ksiądz odpowiedział: „Modlę się do Boga”. Na co sędzia wykrzyknął: „Tutaj zabrania się modlić do Boga!”. Ks. Bukowiński spokojnie odparł: „Niech pan się uspokoi. W przyszłości będę się tak modlić, żeby pan tego nie zauważył"».

Ks. Edward Staniek, komentując Mt 5, 43-44, stwierdza: „Jest to jedna z najbardziej rewelacyjnych i rewolucyjnych nowin Ewangelii. Nowina dobra

\footnotetext{
${ }^{6}$ Tamże, s. 54.

${ }^{7}$ Por. W. Bukowiński, Spotkatem człowieka, Biały Dunajec-Ostróg 2001, s. 87.

${ }^{8}$ W. Bukowiński, Do moich przyjaciót, dz. cyt., s. 51.
} 
dla wrogów, ale dobra także dla uczniów Chrystusa. Trzeba jednak długiego czasu i wielkiej dojrzałości duchowej, by to drugie dobro dostrzec"9.

Życie ks. Władysława jest prawdziwym komentarzem do powyższej Ewangelii i świadczy o jego wielkiej dojrzałości duchowej. Od września 1939 roku był proboszczem katedry w Łucku. 22 sierpnia 1940 roku został uwięziony przez NKWD i przebywał w łuckim więzieniu do 26 czerwca 1941 roku. Opuścił więzienie cudowanie ocalony, ale skrajnie wyczerpany i wynędzniały, a mimo to dalej pełnił powierzoną mu posługę proboszcza w łuckiej katedrze i znowu aktywnie pomagał uciekinierom i jeńcom, ratował żydowskie dzieci, organizował pomoc materialną, zwłaszcza żywność dla głodujących. Dzielił się z potrzebującymi wszystkim, co miał.

W nocy z 3 na 4 stycznia 1945 roku został aresztowany i wraz z biskupem Adolfem Szelążkiem i ks. Karolem Gałęzowskim uwięziony w budynku NKWD w Łucku. W tym czasie zostali aresztowani również inni księża: ks. Bronisław Drzepecki, ks. Stanisław Szczypta, ks. Adolf Kukuruziński, o. Aleksander Bień, ks. Józef Kuczyński. Dla kapłanów był to szczególnie trudny czas, gdyż przez półtora roku nie mogli sprawować mszy świętej. Organizowali jednak wykłady, konferencje, wspólną modlitwę, co nie tylko wzmocniło ich przyjaźń, ale dało wiarę w sens życia. Dlatego w jednym z listów napisał: „Otóż wszędzie, gdzie byłem, widziałem głęboką celowość tego, że tam właśnie byłem”.

Śledztwo trwało do czerwca 1945 roku i zakończone zostało wyrokiem skazujący na 10 lat karnych obozów pracy.

Od lipca 1946 roku przez ponad rok ks. Władysław przebywał w czelabińskim obozie, pracując przy wyrębie lasów i kopaniu rowów. W listopadzie 1947 roku został przeniesiony do obozu w miejscowości Bakał na Uralu. Skrajnie wyczerpany, z ciężkim zapaleniem płuc trafił do szpitala w Czelabińsku. W trudnych warunkach wykorzystywał każdą okazję do apostolstwa.

Od roku 1950 do 10 sierpnia 1954 przebywał w obozie w Dżezkazganie, pracując w kopalni miedzi Pokro.

3 grudnia 1958 roku Bukowiński został ponownie aresztowany i uwięziony za działalność religijną. Na rozprawie 25 lutego 1959 roku oskarżony o nielegalne utworzenie kościoła, agitację dzieci i młodzieży oraz posiadanie literatury antyradzieckiej zrezygnował z obrońcy i wykorzystując swoje prawnicze wykształcenie, sam wygłosił mowę, która wywarła na sędziach ogromne wrażenie. Otrzymał najniższy z możliwych wymiar kary: trzy lata obozu pracy. I tak od marca 1959 roku do czerwca 1961 roku przebywał w obozie pracy w Czumie koło Irkucka, gdzie pracował przy wyrębie lasów.

\footnotetext{
${ }^{9}$ E. Staniek, Kazanie na Górze, Kraków 2003, s. 86.
} 
Zanim został wysłany do łagru, siedział w jednej celi z młodym komunistą. Człowiek ten przedtem nigdy nie słyszał o Bogu i religii. Ks. Władysław w czasie wspólnego z nim pobytu w celi przekazał mu podstawowe informacje o chrześcijaństwie, a on, będąc bardzo inteligentnym, przyswoił je sobie i pragnął dalszego ich pogłębienia. Gdy ks. Władysław opuszczał tę celę, na jego miejsce NKWD umieściło bardzo uczonego jezuite, profesora teologii, który mógł dalej to dzieło prowadzić. Ks. Bukowiński widział w tym opatrzność Bożą.

Ks. Bukowiński spędził w więzieniach i obozach pracy 13 lat 5 miesięcy i 10 dni. Zwolniony z obozu w Dżezkazganie został zesłany do Karagandy: tutaj pracował jako stróż na budowie, a jednocześnie podjął tajne duszpasterstwo. Był pierwszym księdzem katolickim, który przybył do Karagandy. Duszpasterzował wśród Niemców i Polaków. Ks. Władysław tajnie odprawiał msze święte w prywatnych mieszkaniach przy zasłoniętych oknach. On sam tak opisuje tamten czas: „Jestem ustawicznie domokrążcą. [...] Mszę świętą można w naszych warunkach odprawiać raniutko lub wieczorem. Po Mszy świętej zwykle jeszcze spowiedź. Wreszcie krótki spoczynek nocny. Krótki, bo kładę się zwykle po północy, a już o 5 lub 6 rano jest poranna Msza święta, a potem dalej spowiedź, czasami chrzty i namaszczenia olejami świętymi, czasami śluby".

W czerwcu 1955 roku odrzucił propozycję repatriacji do Polski i zdecydował się zostać obywatelem ZSRR, by pozostać na stałe w Kazachstanie. Miał pełną świadomość wszelkich konsekwencji tej decyzji, ale pozostał wierny swojemu powołaniu, gdyż jasno widział potrzebę apostolstwa na tym terenie.

W maju 1956 roku ks. Bukowiński otrzymał paszport i mógł poruszać się po całym ZSRR. Zrezygnował z pracy nocnego stróża i odtąd zajął się wyłącznie duszpasterstwem prowadzonym jednakże w ukryciu, bez pozwolenia, za co mógł być w każdej chwili uwięziony. Nigdy nie nosił urazy i nienawiści do wrogów. Mówił im prawdę w miłości, o czym świadczą powyższe przeżycia. Nie zwracał uwagi na to, czy komuś nie podoba się jego misja, lecz wypełniał zadanie, które zlecił mu Jezus.

Ewangeliczna nauka o miłości nieprzyjaciół, którą tak szczegółowo wyjaśniał św. Jan Chryzostom, była praktycznie realizowana w życiu ks. Władysława Bukowińskiego. Z racji swojego posługiwania w tak szczególnych okolicznościach komunistycznego prześladowania Kościoła miał do tego wiele okazji. Trudne przeżycia kształtowały jego duchowość aż do heroizmu. Mimo tylu przeciwności był coraz bardziej radosny. Nie złamały go niepowodzenia życia. Wprost przeciwnie: wzmocniły go do dalszej służby. Wszystko to ukazuje nam mężnego kapłana, który przebaczając, ratował każdego człowieka, nawet wroga. Dlatego też w modlitwie o jego 
beatyfikację prosimy: „Boże Ojcze, który zleciłeś duszpasterską posługę Twemu słudze ks. Władysławowi nawet w więzieniach i łagrach, obdarzając go wielką wiarą, odwagą i przebaczającą miłością, udziel i mnie tych samych darów potrzebnych do życia Ewangelią we współczesnym świecie”.

Kraków

KS. JAN NOWAK

\section{Zusammenfassung}

\section{Heroismus der Barmherzigkeit von P. Ladislaus Bukowiński}

Gottes Diener P. Ladislaus lebte nach der evangelischen Feindeliebe trotz des Hasses und der Grausamkeiten des kommunistischen Systems. Er hat selber gesagt, dass Christi Gebot der Feindeliebe für ihn keine schöne Utopie ist, sondern etwas Reales und Lebendiges. Diese Feindeliebe äußerte sich in erster Linie im Gebet für Feinde, nicht nur während der Verhöre, sondern auch im Zuge der Verfolgung. Sie kam darin zum Ausdruck, dass man das Gute nach dem evangelischen Prinzip: „Überwinde das Böse mit Gutem!“ tat. Gottes Diener P. Ladislaus beklagte sich nie über seine Feinde, war nie über sie zornig, sondern war die ganze Zeit von der Verkündigung der Liebe Christi ergriffen.

Der Totalitarismus untersagte, sich zum Gebet zu versammeln. Das Ziel war, den christlichen Glauben zu vernichten, indem der Hass gegen Christen verbreitet wurde. Obwohl er so viel Furchtbares in Gefängnissen und Lagern gelitten hat, dabei zu 13 Jahren Gefängnis unschuldig verurteilt wurde, trug er nie Hass im Herzen. Im Gegensatz. Er versuchte es zu rechtfertigen, dass nicht die Feinde schuldig sind, sondern das kommunistische System.

Die Kraft, die diesen blinden Hass besiegt, ist die Vergebung. Das Vertrauen in die Kraft der Vergebung war bei P. Bukowinski rundweg heroisch. 